\title{
THE SECURITIES ACT AND CORPORATE REORGANIZATIONS
}

\begin{abstract}
Age Fortas*
In 1934, Congress directed the Securities and Exchange Commission to make an investigation of reorganization and protective committees and to report the result of its study and its recommendations. ${ }^{1}$ The Securities Act of 1933 was not designed to provide controls over corporate reorganizations. ${ }^{2}$ Comparatively few reorganizations are subjected to the regulatory provisions of the Act, and no specialized treatment is provided for even these cases. Moreover, observation of the current cycle of reorganizations and the detailed investigations made by the Commission, pursuant to Congressional direction, have shown that adequate controls over reorganizations do not elsewhere exist-that controls are necessary and that existing regulatory machinery is inadequate. ${ }^{3}$ It is, therefore, timely and important to canvass the theory and operation of existing controls so that new machinery may be devised which will be effective for the purpose of inducing reorganizations which are fair and economically sound.

It is likely that most reorganizations are to some extent affected by statutory or judicial controls. It is probable that only a small percentage of changes in the rights of existing security holders is accomplished by purely consentual machinery. ${ }^{4}$ In a few states, even the alteration of preferential rights is affected by statute designed to give to dissident security holders the right of appraisal as an alternative to acceptance
\end{abstract}

- A.B., Southwestern College, I930; LL.B., Yale University, 1933. Assistant Professor of Law, Yale University. Assistant Chief, Marketing Agreement and Licensing Section, Agricultural Adjustment Ad. ministration, 1933 to 1935; Assistant Director, Protective Committee Study, Securities and Exchange Commission, since 1933. Author of Wage Assignments in Chicago (1933) 42 YALE LAw Journal, 526.

Nothing in this article may properly be taken as an expression of opinion of the Securities and Exchange Commission or of the Protective Committee Study of that Commission.

${ }^{2}$ Securities Exchange Act, \$21 I.

"The term "reorganizations" is used in this article in its broadest sense, to include capital readjustments, debt rearrangements, merger, consolidation and sale of assets as well as reorganizations in receivership or bankruptcy or by means of foreclosure.

Sec S. E. C. Report on the Study and Investigation of Protective and Reorganization ComLatTeEs (1936) Pts. III, IV, VI.

t Of this type are reorganizations effected by unanimous consent, which are probably rare, and changes in various provisions of securitics by less than unanimous consent, pursuant to or in reliance upon provisions of charter or trust indenture. See, e. g., S. E. C., op. cit. supra note 3, Pt. VI, Pp. I 43 et seq., "Reorganization by Contract." To be distinguished are instances in which reorganization is effected pursuant to or by aid of statutory or judicial machinery. 
of the proposed modification of security. ${ }^{5}$ The right to appraisal is also commonly available in respect of merger, consolidation or sale of assets, the procedure for effecting these being governed by legislative enactment. ${ }^{6}$ Even the appraisal statute, distant as it seems from control over the processes of modification of rights, unquestionably exerts some restraint upon a putative tendency of the reorganizers to seek from a class of security holders inequitable sacrifices. Such restraint is the product of fear that, unless equity is done, the number of those whose securities must be appraised and purchased will be increased.

Universal, and more elaborate than the above, are the controls which exist when a corporation undertakes to reorganize in the equity or bankruptcy courts. There the court has, generally speaking, control over the fairness of the plan and its conformity with the law of the land, and residual jurisdiction over other aspects of the reorganization. ${ }^{7}$ A few states, moreover, have provided elaborate machinery for the regulation of the activities of protective committees. ${ }^{8}$ Only in a limited field is anarchy complete. In jurisdictions where appraisal statutes are not applicable to alteration of preferential rights, reclassification of capital stock has taken place upon the level of supposedly free contract-without other sanction or control. ${ }^{9}$ Complete reorganizations of debt as well as capital structure sometimes take place upon this level, with the aid of the doctrine of the Moline Plow case. ${ }^{10}$ In such situations, only the jurisdiction of equity courts to enjoin fraudulent or grossly unfair action is an available restraint. ${ }^{11}$

It is not possible within the limited scope of this article to show that control over reorganizations is necessary, and to demonstrate that existing controls are inad-

-See, e. g., N. Y. Consol. Laws (Cahill Supp. 1931-1935) c. 60, 538; Onio Gen. Code (Page Supp. 1932) 58623-72. Concerning appraisal statutes generally, see Lattin, Remedies of Dissenting Stockholders under Appraisal Statutes (I93I) 45 Harv. L. Rev. 233; Weiner, Payment of Dissenting Stockholders (r927) 27 Cor. L. REv. 547; Levy, Rights of Dissenting Shareholders ta Appraisal and Payment (1930) 15 CORN. L. Q. 420.

'See, e. g., N. Y. Consol. Laws (Cahill Supp. 1931-1935) c. 60, 5\$20-21; 85-87; id. (Supp. 1936) c. $60,5521,85$.

The extent of this residual jurisdiction in receivership is subject to debate. Compare Developments in the Law-77B (1936) 49 Harv. L. REv. IIII, II57; In re Republic Gas Corp., C. C. H., BanxuUptCy SERvice, par. 3721 (S. D. N. Y. 1935).

${ }^{B}$ See the California Corporation Commission, Cal. Code (Deering, Supp. 1935) Tit. 280, and the Michigan Public Trust Commission, Mrch. Comp. Laws (Mason's Supp. 1933) 5290 and especially \$290-3.

- Proxies solicited for such purposes, in respect of securities registered on a national securities exchange, are subject to the regulations of the Commission under $5 \mathrm{r}_{4}(\mathrm{a})$ of the Securities Exchange Act. See discussion infra. Note also the applicability of the Securities Act unless exemption is available under $\$ 3(a)(9)$, discussed infra, p. 224 .

${ }^{10}$ Allan v. Moline Plow Co., I4 F. (2d) 912 (C. C. A. 8th, 1926). In brief, this type of reorganization is based upon usual provisions in trust indentures requiring demand by $25 \%$, for example, of the bondholders before suit can be instituted. When the consent of $76 \%$ of the bondholders has been obtained, the reorganization can be effected, the minority having no remedy. Cf. S. E. C., op. cit. supra note 3 , Pt. VI, pp. 62-63 et passim.

"See, e. g., Homer v. Crown Cork \& Seal Co., I55 Md. 66, 84, 85, I4I Atl. 425, 434 (1928). See also the interesting case of Wilson v. Waltham Watch Co., 293 Fed. 8I I (D. Mass. 1923). The California statute purports to make the appraisal remedy exclusive of any other remedy, even though the remedy is sought upon the grounds of fraud. See CaI. Clv. CoDE (Deering I93I) \$369, and Ballantine, Drafting a Modern Corporation Law (1931) ig CAL. L. REv. 465, 482. 
equate. $^{12}$ The following discussion will be restricted, in general, to an appraisal of the effect of the Securities Act upon existing reorganization practice and to an analysis of the adequacy of the theory of disclosure to provide the desired control over reorganizations. ${ }^{18}$

\section{Section 17 (b) of the Securities Act}

At the outset, it is desirable to refer to a section of the Act which is, in a sense, collateral to its principal scheme, registration of security issues. Section 17 (b) makes it unlawful to give publicity to any description of a security, though the security is not thereby offered for'sale, if the person publishing the description has received or will receive a consideration therefor, unless such consideration and the amount thereof are disclosed. The "tipster" who offers advice apparently unbiased, but in reality bought and paid for, has long been a hazard in reorganizations as well as in other fields of financial activity. On December 28, 1933, the Federal Trade Commission issued a release affirming the applicability of this section to reorganizations.14 The release stated that a securities statistical service was employed to assist in preparing a plan of reorganization. The company was to receive a flat fee, not contingent upon the success of the reorganization. It proposed to recommend in its pamphlet that bondholders of the corporation being reorganized deposit their bonds under the plan. The Commission held that if the fee was contracted for with the understanding that the reorganization plan would be recommended by the company, the proposed consideration and the amount thereof would have to be disclosed.

The effect of this provision of the Act and of the Commission's opinion is evidenced by an incident developed in the course of a hearing held as part of the study of protective committees under Section 2r.I of the Securities Exchange Act. ${ }^{15}$ A plan of reorganization for a public utility holding company ${ }^{16}$ controlled by an investment banking house ${ }^{17}$ was formulated. It was to be submitted to security holders by two protective committees formed by the investment house and its associates. ${ }^{18}$ A prominent statistical agency ${ }^{10}$ agreed to study the plan. ${ }^{20}$ If the agency decided that the plan was practicable and equitable, the reorganization committee would state in its literature that the investment agency unqualifiedly recommended acceptance of the plan. ${ }^{21}$ For this, the agency was to receive a fee of $\$ 5,000.22$ But on November 22, 1933, according to the record, the agency received a ruling from the Federal Trade Commission to the effect that the fee would have to be disclosed

\footnotetext{
12 Reference is made to the published and forthcoming reports of the Securities and Exchange Com. mission to Congress under \$2II of the Securities Exchange Act. See note 3, supra.

${ }^{12}$ See also Legislation Note, Reorganization of Corporations and the Securities Act (1934) 34 Cot. L. Rev. 1348; Edminster, Security Reorganization under the Securities Act (1933) Proc. Nar. Ass'N Securtties Comm'rs I45.

"Securities Act Release No. 97, pt. 15; C. C. H., Stocks \& Bonds Service, Vol. III, par. 4764.02.

${ }^{15}$ Hearing before the S. E. C., In the Matter of Federal Public Service Corporation (1935), Pp. 725 ef seg.

${ }^{20}$ Federal Public Service Corporation. ${ }^{27} \mathrm{H}$. M. Byllesby \& Co.

Op. cit. supra note 15 , at $608,739-741,748,627-628,641$.

Standard Statistics Company, Inc.

"Id., at 727 .
} 
in order to avoid violating Section ${ }^{2}$ (b) of the Act. ${ }^{23}$ Rather than make such disclosure which, presumably, would adversely affect the company's reputation for impartial investment service, it surrendered all claim to compensation. The committee was allowed to state that the agency had examined and approved the plan, but no fee was paid. ${ }^{24}$

This incident evidences, I believe, a clear advance in reorganization practice along the difficult road to elementary decency. Section $\mathbf{1 7}$ (b) seems equally applicable to persons who are hired by reorganizers to solicit assents or are paid for the assents or deposits which they have procured. Undisclosed paid solicitation, sometimes by commercial banks or by brokers who occupy a position of some trust in respect of their clients, has been an obvious evil in reorganization practice. ${ }^{25}$ Disclosure of the receipt of compensation may be awkward and embarrassing to the solicitor who in the past has secmed to urge deposit or consent because of friendship or altruism; but it is a minimum standard for fair and honest conduct.

So far as appears, then, Section ${ }^{2}$ (b) of the Securities Act, in respect of reorganizations has laid down a definite and salutary rule. But the abuse which it forbids is, after all, of minimum importance in comparison with the practices which it leaves untouched. In general, the Securities Act, so far as it affects the remaining practices in any way, does so through provisions for registration of security issucs. Under other acts which it administers, the Securities and Exchange Commission exercises additional jurisdiction over reorganizations. Under the Public Utility Holding Company Act of 1935, the Commission has comprehensive control over the reorganization of registered utility holding companies. ${ }^{20}$ Two provisions of the Securities Exchange Act of 1934 ate important in reorganization. Pursuant to Sections 12 (a), (b) and (c), securities (including certificates of deposit) traded on a national securities exchange, except exempted securities, must be registered. ${ }^{2 T}$ Section 14(a) of the Securities Exchange Act of 1934 empowers the Commission to regulate the solicitation of proxies "in respect of any security (other than an exempted security) registered on any national securities exchange" and makes violation of the Commission's regulations unlawful. ${ }^{28}$ Reference to the latter provision of the Exchange Act will hereafter be made in connection with various aspects of Commission regulation under the Securities Act; otherwise, both the reorganization

= Id., at 728-729.

Id., at 730-73I.

- Cf. dicte in S. E. C. v. Torr, 15 F. Supp. 315 (S. D. N. Y. April ro, 1936).

- Sec especially $\$ 5 \mathrm{I}$ (f) and II (g).

- Ability to effect the listing of reorganization securities is sometimes critical to success of the reorganizers. Obviously, if certificates of deposit offered by a committee can be traded on an exchange, they are mare attractive to security holders. By the same token, 2 committec which has not listed its certificates may find it difficult to persuade holders to exchange listed securities for unlisted certificates.

- See the regulations of the Commission pursuant to this section. Securities Exchange Act Release No. 378, Class A, Sept. 24, 1935, C. C. H., Stoce Exchasce Senvice, pars. 5281-5285 C. These regulations, in general, require filing of a form of the proxy used and disclosure of specified types of facts. They fortid false or mislading tatements of material fact in the course of solicitation. Ther also require the iscuer or its management soliciting proxies to mail proxy and circular forms furnished by any security boldar "to erery recoed bolder" solicited by the management. 
provisions of the Public Utility Act and the provisions of the Securities Exchange Act are beyond the scope of this paper. ${ }^{29}$

\section{Registration Under the Securities Act-In General}

The broad plan of the Securities Act, in so far as it affects reorganizations, is to require full disclosure of material facts concerning the securities offered as an intermediate or final step in reorganization. Unless an exemption is available, the "issuer" of certificates of deposit, ${ }^{30}$ which may be a protective committee or the reorganizing corporation, and the issuer of the securities exchanged under the reorganization plan for outstanding securities must effect registration with the Commission. $^{31}$

Reorganization procedure is traditionally such that disclosure of information concerning the securities issued in exchange under the reorganization plan is generally of secondary importance to the investor whose securities are involved in the process. Before such registration statement is filed, he is likely to have surrendered irrevocable power and dominion over his securities to a protective committee. Registration of the securities to be issued under the plan will usually come too late to benefit him. Of primary importance will be information concerning the protective committee which asks for his power of attorney, with or without custody of his securities.

There can be little dissent from the proposition that security holders are entitled to as complete information from those seeking their proxy or the deposit of their securities as it is practicable to convey. But the history of reorganizations shows that security holders have generally received declarations of pious intention, intimations of threatening disaster, and urgent calls to union instead of facts as to the interests and plans of those asking for control of their securities. The security holder has received a circular letter from the group soliciting his support; he has not received a copy of the deposit agreement describing the rights which he surrenders and which the protective committee acquires. Neither the circular letter nor the

\footnotetext{
- Mention should also be made of $\$ 12$ (d) of the Securities Exchange Act which authorizes the Commission to impose conditions upon delisting. Delisting of securities called for deposit may be used in reorganization to exert pressure upon security holders to exchange their securities for listed certificates of deposit. The decline in market value of the called securities together with fear of loss of liquidity which may result, may induce hesitant holders to deposit their securities. Cf. Hearing before the S. E. C., In the Matter of the Celotex Company (1935) pp. 390 et seq.

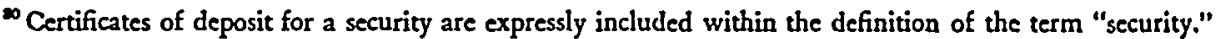
Securities Act, $\mathbf{S 2}_{2}(\mathrm{r})$. It is possible that some proxies, authorizing the holder to act for the owner of the security for purposes of reorganization and vesting substantial powers in the holder, may be considered "securities" and therefore subject to the registration requirements of the Securities Act. See id., \$2(1). The Commission has not as yet ruled upon this question.

By amendment to the Act in 1934, members of the usual type of protective committee were relieved of individual liability as "issuers" under the Act. Id. \$2(4).

"For the registration requirements of the Act, see $\$ \$ 6$ and 7 and Schedules $A$ and B of the Act, and the various forms prescribed by the Commission, particularly Form D-I (for certificates of deposit registered by protective committees) and Form D-IA (for certificates of deposit registered by the issuer of the securities called for deposit).
} 
deposit agreement has described a plan of reorganization which the committee proposes or endorses. In a few instances, it is true, this is not the case. In these, a plan of reorganization is described to security holders when their consent is solicited. But in the great majority, presumably a plan of reorganization has not been formulated when the committee asked for deposits. In these, the committee asks security holders to give it blanket power over their securities, to be used in favor of such reorganization plan as the committee may later propose or approve. To the depositor is given only the privilege to withdraw his securities within a limited time if he does not like the committee's plan; and, in order to evidence his dissent, he must pay an assessment. Knowledge of the ways of investors and studies of actual behavior make it clear that this is in substance a denial of the privilege to dissent.

The security holder is given no information by which he may judge the reliability or the qualifications of the committee to bear this broad trust. Unless he has independent knowledge of the members of the committee, he remains unenlightened as to their connections, and even if the security holder knows the committee members, he probably is not aware of their financial interest in the reorganization. Only rarely do deposit agreements make any disclosures of the business affiliations of committee members, and most of these are merely statements of the principal business of the members. The deposit agreement generally neglects to state whether the members of the committee own any of the securities which they purport to represent or if they own securities with conflicting claims. The security holder, therefore, in a large majority of cases, deposits his securities with a committee concerning whose interests he knows little or nothing and of whose plans he is not informed.

Whether the security holder relies upon his own judgment or hunch, or acts upon the advice of investment counsel, broker or banker, lack of information makes impossible informed judgment. If all committees were required to register under the Securities Act, this deficiency might be supplied. But as I have previously stated, the registration requirements of the Act are applicable to very few committees.

From the effective date of the Act to September I, 1936, 302 registration statements were filed for certificates of deposit. Of these, 287 were filed by protective committees and 15 by corporations in reorganizations. Hundreds of protective committees and corporations, in addition to these, during the same period were, without doubt, soliciting proxies and deposits of securities. Most of these, it is clear, were exempt from the provisions of the Act by virtue of Section $3(a)(I)$, because they had issued certificates of deposit prior to the effective date of the Act. But many which commenced activity after the effective date were exempt under other provisions of the statute. I believe that it is a conservative estimate to say that about 75 per cent of all committees commencing to operate after the effective date of the Act would not have to comply with the registration provisions of the Act. 


\section{Exemptions UNDER the $\mathrm{AcT}^{32}$}

Many of these committees are exempt under Section 3(a) (10) of the Act, on the ground that the terms and conditions of the issuance and exchange of the certificates of deposit had been approved, after hearing, by a court or authorized agency of the United States or of a State. ${ }^{33}$ Others are exempt under Section 3(a)(2). These are principally committees representing securities issued by drainage and irrigation districts and by municipalities. A few need not register because of Section 3(b) of the Act, on the ground of the small size of the issue, and under Section 3(a) (4) because they represent securities of eleemosynary institutions. A number are exempt under Section 3 (a) (9), because they are acting in connection with the exchange of securities by an issuer "with its existing security holders exclusively where no commission or other remuneration [was] paid or given directly or indirectly for soliciting such exchange." A small number are exempt under Section 3(a)(II), since their activities are intrastate, as therein defined.

There is reason to believe that in the future the number of committees which must register under the Act will be infinitesimal. Resort to Section $77 \mathrm{~B}$ of the Bankruptcy Act is becoming more frequent, and exemption from registration of certificates of deposit available in $77 \mathrm{~B}$ proceedings is being obtained by correspondingly more committees. ${ }^{34}$ Since August 27, 1935, Section 77 of the Bankruptcy Act has exempted protective committees in reorganizations of railroads under that section from the registration requirements of the Securities Act. ${ }^{35}$ In addition there is some reason to forecast that committees and corporations in reorganization will increasingly use proxies or assents of a type which are not required to be registered. ${ }^{30}$ The tendency to operate in this fashion is undoubtedly accentuated by the requirement in the Securities Act for registration of certificates of deposit, as well as by the use of Section $77 \mathrm{~B}$ of the Bankruptcy Act as a medium for reorganizations. It is not necessary for a committee to have title to or possession of the securities in order to effect reorganization under $77 \mathrm{~B}$. For example, in the recent reorganization of The Baldwin Locomotive Works, neither the consolidated bondholders committee nor the preferred stockholders' committee solicited deposit of securities. Edward

\footnotetext{
${ }^{3}$ For a thorough treatment of this matter, see Throop and Lane, Some Problems of Exemption under the Securities Act of 1933 (Jan. 1937) 4 LAw and Contemporary Problenss, 89.

${ }^{25}$ Exemption under this section, it should be remembered, may be granted by a state commission or official, properly authorized, as well as by a state or federal court.

${ }^{34}$ Securities Act, $\$_{3}(\mathrm{a})(\mathrm{10})$, and see Bankruptcy Act, $\$ 77 \mathrm{~B}(\mathrm{~h})$. The latter contains an exemption from the Securities Act for securities issued pursuant to a confirmed plan under $77 B$. It is not clear whether it applies to certificates of deposit. The difficulty is indicated by the following quotation: "All securities issued prersuant to any plan of reorganization confirmed by the court . . . including . . . all certificates of deposit representing securities of or claims against the debtor which it is proposed to deal with under any such plan, shall be exempt ..." (italics supplied).

${ }^{35}$ See $\$ 77(\mathrm{f})$. This exemption is applicable only if the issuer of the certificates of deposit is subject to $\$ 77(\mathrm{p})$. The latter section forbids, in general, solicitation of deposits or proxies for reorganization purposes except with the approval of the Interstate Commerce Commission. It exempts from its scope, among others, groups of not more than twenty-five security holders "acting for their own interests and not for others," through representatives or otherwise. For the 1. C. C. regulations governing solicitation under \$77, see C. C. H., Bankruptcy Law Service, par. 2001.

${ }^{*}$ See note 30 , supra.
} 
Hopkinson, Jr., partner of J. P. Morgan \& Co. and Drexel \& Co., and chairman of the consolidated bondholders' committee, testified before the Securities and Exchange Commission as to the reason for soliciting proxies rather than deposits: ${ }^{37}$

“Q. Why didn't your committce accept deposits or ask for deposits?

A. There were a variety of reasons. With the probability that the ${ }_{77} \mathrm{~B}$-procedure would be followed in the rearganization, it was extremely probable that deposits would never be required, and it would have involved, as we understood it at that time, registration of certificates of deposit, and a lot of expense which we wanted to avoid if possible.

A. We hoped to avoid the expense of it, and if $77 \mathrm{~B}$ was the method to be pursued, deposits would be unnecessary." 38

John Converse, chairman of the preferred stockholders' committee, stated the same reasons for not soliciting deposits, and added that the committee also wished to avoid listing certificates of deposit on the exchange. 39

Proxies or assents solicited for the purpose of reorganization under $77 \mathrm{~B}$ are exempt from Commission control not only under the Securities Act, but also under Section $\pi_{4}(\mathrm{a})$ of the Securities Exchange Act. ${ }^{40}$ Similarly, proxies generally solicited for purposes of railroad reorganization under Section 77 of the Bankruptcy Act are exempt from the control of the Securities and Exchange Commission.11 And in any event the Commission's power over the solicitation of proxies under the Exchange Act is applicable only in respect of securities registered on a national securities exchange. The result is that a large proportion of proxies solicited in reorganization proceedings is free from Commission control under both Acts. In fact, the only type of reorganization which has been subject to the Commission's regulations under Section $\mathrm{r}_{4}(\mathrm{a})$ in any volume is reclassification of capital stock. Prior to the recent decision of the Supreme Court of Delaware in Keller v. Wilson \& $\mathrm{Co} ._{.}{ }^{42}$ a great many corporations sought to reclassify their stock and to eliminate unpaid dividends on their preferred stock which had accumulated during the depression. Many of the endeavors to solicit proxies in order to consummate plans came within the Com-

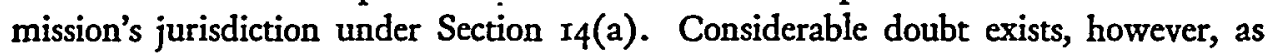
to the adequacy of the Commission's power even in respect of this limited type of case. It is beyond the scope of this article to analyze this situation. ${ }^{33}$

"r Hearing before the S. E. C., In the Matter of The Baldwin Locomotive Works (1935) p. 414.

- Witnesses in other hearings before the Commission gave similar reasons for not soliciting deposits.

- Op. cit. supra note 37 , at 435-436.

${ }^{\infty}$ Securities Exchange Act Release No. 461, Jan. 21, x936, C. C. H., Stock Exchange Service, par. 2754.01 .

${ }^{4}$ 77 (f); C. C. H., op. cit. supra note 40, par. 2753 A.

'Not yet reported. See N. Y. Herald Tribune, Nov. 11, 1936. This decision overruled an earlier decision of the Delaware Chancery Court in Morris v. American Public Utilitics Co., I4 Del. Ch. 136, 122 Atl. 696 (1923).

"See the case of Consolidated Film Industries, Inc. This company filed with the Commission a copy of its material for soliciting assents to a proposed recapitalization. It appeared to the Commission that certain of the statements therein "might" be misleading. The company, however, refused to rectify the claimed deficiencies or to appear before the Commission to defend its position. Rectification would probably have involved re-solicitation of proxies. The Commission therefore made public an opinion stating the alleged misleading statements. This opinion was published the day before a scheduled stock- 
With respect to the situations which are exempt from registration under the Securities Act, it is important to ascertain, first, whether an adequate substitute for the disclosure requirements of the Securities Act is applicable to them; and second, whether other adequate controls are applicable, which may be different in kind from the provisions of the Act. The reasons for the exemptions are moderately clear. It must be borne in mind that most of the sections conferring exemptions are not peculiarly directed to reorganizations. Certain of them, like those excluding issues offered prior to the effective date of the Act ${ }^{44}$ and issues sold only intrastate by an issuer resident and doing business within the state, ${ }^{45}$ were probably induced by legal considerations, and by desire to reduce the total administrative load. Constitutional difficulties may also have influenced the exemptions of governmental and quasi-governmental issues, ${ }^{46}$ although it is not clear that those difficulties make necessary exemption of certificates of deposit for such issues. ${ }^{47}$ In addition, this exemption may have been motivated by administrative difficulties which may be inherent in any endeavor to regulate governmental and quasi-governmental agencies. In any event, a Report of the Securities and Exchange Commission to Congress has shown the necessity of regulating the readjustment of the funded debt of municipal and certain types of quasi-municipal securities. ${ }^{48}$ This Report discusses the virtually complete lack of control over this process and the necessity for comprehensive regulation.

Desire to reduce the total administrative load and to refrain from imposing disproportionate burdens upon small issuers probably motivated Section $3(\mathrm{~b})$, which permits the Comimission to exempt small issues. The most significant exemptions, in so far as reorganizations are concerned, are those provided by Sections 3(a) (9) and 3 (a) (ro) of the Act. From the viewpoint of protection of security holders, it is to be supposed that these exemptions are based on the assumption that the method of reorganization to which they relate makes unnecessary disclosure under the Securities Act. In addition, the exemption under Section 3(a)(xo) may have been motivated in part by a desire to avoid overlap and possible conflict with the courts and other governmental agencies.

holders' meeting to ratify the plan. It received considerable publicity in the newspapers. Sec $N . Y$. Herald Tribune, Oct. 22, 1936. Nevertheless, the plan was confirmed at the stockholders' meeting. Id., Oct. $24,1936$.

The New York Supreme Court had denied complaining stockholders an injunction restraining holding of the meeting. N.Y.L. I., Oct. 24, 1936, at p. 1347. Subsequently, however, the chancery court of Delaware issued an order restraining the company from filing a certificate of amendment of its charter, pending determination of proceedings to show cause. N. Y. Times, Nov. 1, 1936. After the decision in Keller v. Wilson \& Co., supra, the plan was at least temporarily abandoned. N. Y. Herald Tribune, Nov. 18, 1936.

"Securities Act, $\S_{3}(\mathrm{a})(\mathrm{I})$.

${ }^{20} I d ., \S_{3}(\mathrm{a})(2)$. Cf. Ashton v. Cameron County Water Improvement District No. 1, 56 Sup. Ct. 892 (U. S. 1936).

47 The inclusion of certificates of deposit within the scope of this exemption was added by amendment in 1934.

${ }^{48}$ S. E. C., op. cit. supra note 3, Part IV. See also Report of Hon. J. Mark Wilcox in Public Hearings of a Sub-committce of the Selcet Committce on Investigation of Real Estate Bondholders' Reorganization, House of Representatives, $74^{\text {th }}$ Cong. Ist Sess., Nov. II-13, 1935, Part 11, pp. I-11. 
Section 3(a) (9) is not, of course, generally applicable to certificates of deposit issued by protective committees in exchange for outstanding securities. The committee is not the "issuer" of the securities for which the certificates are exchanged. But if no protective committee intervenes, and if the issuer offers new securities to its "existing security holders exclusively where no commission or other remuneration is paid or given directly or indirectly for soliciting such exchange," no registration statement need be filed. If the issuer solicits proxies for securities registered on a national securities exchange, disclosures will have to be made under the Commission's regulations pursuant to Section $\mathrm{I}_{4}$ (a) of the Exchange Act, as previously discussed. In most cases, however, and for the most part, the issuer is in complete control of the terms which it offers to security holders and of the methods and manner of solicitation of approval of the proffered exchange. In substance, this means that the directors of the corporation and its bankers are in a position, without check or restraint except such as is supplied by an infrequent opposition group, to carry out whatever reorganization plan they may conceive. It is impossible in this article to analyze and discuss the dangers implicit in this procedure. The Securities and Exchange Commission in the course of its study of protective committees has investigated a number of instances in which so-called voluntary plans proposed by management and bankers have promoted interests of the proponents, adverse to those of security holders. ${ }^{49}$ In some of these, the financial stake of the reorganizers was in securities or claims competitive with those of security holders; or management and bankers were confronted with possible legal liability to the corporation or to security holders, risk of the imposition of which would be averted by reorganization. ${ }^{50}$ The supposed familiarity of security holders with the affairs of their corporation and its controlling personnel is no defense for them against management and bankers so motivated. They have not the information with which to challenge the case made by the management and bankers in favor of the plan; they have no means of compelling such information; and if they could obtain it, it is questionable if they could use it advantageously. Their training might not equip them to comprehend its intricacies; or their judgment might indicate that it is useless to resist. In most reorganizations of this sort, even appraisal of the stock of dissenters is not available as a remedy for the dissident and a check upon the reorganizer, and it probably does not require argument to show that the appraisal statute, even where it applies, is not always an adequate or a completely happy control. Apart from the appraisal statutes, control over these voluntary reorganizations exists, by and large, only in the jurisdiction of equity courts to enjoin extreme cases where fraud or gross unfairness can be shown. ${ }^{51}$ The exemption of such cases, then, granted by Section 3(a) (9) of the Securities Act cannot be accepted as meaning that control

`See, e. g., S. E. C., op. cit. supra note 3, Part III, pp. 44-48. Other instances of this sort will be discussed in forthcoming parts of the Commission's Report to Congress.

${ }^{50}$ Ibid. A notable instance of control of reorganization by management and bankers subject to possible legal liability is the attempted "voluntary" reorganization of the Frisco road in 1932. See Hearings before the S. E. C., In the Matter of St. Louis-San Francisco Railway Co. (1935).

See notes 5 and $\mathrm{IT}$, supra. 
over such reorganization is not necessary. On the contrary, it leaves clear and unobscured the necessity for regulation. ${ }^{\overline{2}}$

Appraisal of the cases exempted by Section 3(a)(10) of the Securities Act, and consideration of the adequacy of the controls exercised by existing state and federal agencies, contemplated in Section $3(\mathrm{a})$ (ro), require extended treatment far beyond the scope of this article. Reference must be made to a forthcoming Report of the Securities and Exchange Commission to Congress, which will analyze this situation in detail. This Report will, it is contemplated, relate and discuss the activities of receivership and bankruptcy courts, of the Interstate Commerce Commission ${ }^{53}$ and of various state agencies like the Michigan Public Trust Commission, ${ }^{54}$ in supervising and controlling reorganizations. In this article, I can make only a few observations with respect to the work of federal courts under Section $77 \mathrm{~B}$ in supervising the reorganization process.

\section{Supervision OF COMMITTEes UNDER $77 \mathrm{~B}$}

It is of course dangerous to venture wholesale comment concerning the quality of supervision which courts have exercised under the broad powers of Section $77 \mathrm{~B}$. The character of administration has varied from district to district and from judge to judge. But it is comparatively safe to say that under $\eta^{B} \mathrm{~B}$ investors whose securities are involved in reorganization have not received a new deal. The traditional has been taken as the standard. For example, instances are known in which protective committees have won approval of the "terms and conditions" of issuance of their certificates of deposit, making available the exemption under Section 3(a)(10) of the Securities Act, by displaying other deposit agreements containing the same provisions. And in other respects, the much criticized pattern of behavior before $77^{B}$ became law has been accepted as the norm for procedure under the new statute. ${ }^{\text {bs }}$

Section $77^{\mathrm{B}}$ gives the courts extremely broad powers over the reorganization process. In particular, they may disregard "any limitations or provisions of any depositary agreements, trust indentures, committee or other authorizations. . .."66 Under Section $77 \mathrm{~B}(\mathrm{~h})$; "All securities issued pursuant to any plan of reorganization confirmed by the court" are exempt from registration under the Securities Act. This section may or may not exempt all or certain certificates of deposit issued as part of the process of reorganization..$^{\mathbf{5 7}}$.In any event, exemption of certificates of deposit is available if the procedure of Section 3(a) (ro) of the Securities Act is followed.

There is, in fact, evidence that the conditions precedent to exemption, contained in 3 (a) (ro), have become little more than a specification of procedure. Before

${ }^{s 2}$ Facts which have been developed in current hearings of the Securities and Exchange Commission, in the course of its study of investment trusts (under the Public Utility Holding Company Act of 1935, 530) emphasize this necessity. Reference to the record of these hearings will disclose many instances of merger, consolidation and reclassification of stock which seem motivated solely by promotional schemes of those in control, detrimental to many of the affected security holders.

$\approx$ See note 35, supra.

${ }^{\infty}$ See Douglas, Protective Committees in Railroad Reorganizations (1934) 47 HArv. L. Rev. 565; Dodd, Reorganization Through Bankruptcy (1935) 48 id. 1roo; Lowenthal, The Stock Exchange and Protective Committee Securities (1933) 33 Col. L. REv. I293.

${ }^{\infty}$ See $\$ 77 \mathrm{~B}(\mathrm{~b})$.

or See note 30 , supra. 
solicitation of deposits, committees participating in reorganizations under $77^{\mathrm{B}}$ will file with the court a petition for approval of the "terms and conditions" of issuance and exchange of their certificates of deposit. ${ }^{68}$ In most cases, if the deposit agreement is in conventional form, such approval is granted and exemption follows. Indeed, committees, far from being subjected to additional restraint by this procedure, have usually managed to emerge with a net profit. Having obtained court approval the committee proceeds, with the court's permission, to print on its circulars a statement that the court "has approved the fairness of the terms and conditions of the issuance and exchange by this Committee of the certificates of deposit. . . . Such approval, however, is not to be deemed to mean that any Plan of Reorganization ... has been approved by said Court." 59 .That statements of this sort aid the committee to persuade security holders to deposit, seems clear.

Unfortunately, however, the court's approval does not always follow careful scrutiny. Indeed, instances of exercise of the court's scrutiny power under $77 \mathrm{~B}$ are not frequent, although some improvement in this respect may be noted, as compared with the control exercised in the old equity reorganizations. I believe that the following conclusions, based upon general observation and upon detailed study of a sample group of ${ }_{77} \mathrm{~B}$. cases in two federal districts, is moderately well-supported:

1. In individual cases, judges have exercised active and detailed control; ${ }^{60}$ but the aggregate quality of administration does not bear this characteristic. ${ }^{61}$

\footnotetext{
- Apparently, this petition is filed at or shortly after the time of filing petition to intervene. Sometimes petition for approval is filed at or about the time of confirmation of plan. The purpose of the latter may be to prepare the way for solicitation of deposits under the confirmed plan; or broad approval of committec activities may be sought 25 a basis for allowances in the proceedings or as possible protection from suit against the committee.

- In re Saenger Theatres, Inc., C. C. H., Bankruptcy Service, par. 308i (E. D. La. 1934).

- See In re Butterick Co., C. C. H., Banknuptcy Senvice, par. 3595 (S. D. N. Y. 1935) (in course of holding that bondholder could address communication to others of his class, court specified requirements for contents of communication), with which compare In re Schroeder Hotel Co., U. S. Law Week, November 24, 1936, at p. 3 (C. C. A. 7th, 1936) (court enjoined committee from communicating with bondholders on ground that its communications had been false, misleading and generally obstructive); In re Rosenbaum Grain Co., C. C. H., Banxouptcy Service, par. 3468 (N. D. Ill. I935) (court assumed general supervision over work of committees). For cases showing the exercise of jurisdiction over fees and expenses, see In re Republic Gas Corp., id., par. 3721 (S. D. N. Y. 1935); In re De Witt Clinton Co., II F. Supp. 829 (S. D.-N. Y. 1934); In re Wayne Pump Co., 9 F. Supp. 940 (N. D. Ind. 1935); In re A. Herz, Inc, C. C. H., Banxaupicy Service, par. 3806 (C. C. A. 7th, 1936); In re The Celotex Co, id., par. 3608 (D. Del. 1935), with which, however, compare Hearing before the S. E. C., In the Matter of The Celotex Company (1935); In re Kentucky Electric Power Corp., II F. Supp. 528 (W. D. Ky. 1935); see also In re Kelley-Springfield Tire Co., C. C. H., Banknuptcy Service, par. 3720 (D. Md. 1935). See also the interesting case of In re 1775 Broadway Corp., 79 F. (2d) 108 (C. C. A. 2d, 1935) (couft struck out provision in plan releasing liability of trust company which was trustee for, and underwriter of, the notes).
}

As to supervision of allowances under $77 \mathrm{~B}$ generally, see Alley, Some Corporate Reorganization Problems (1936) 22 A. B. A. J. 557.

The tendency of some courts to disallow expenses and compensation to independent committees and groups on the grounds of "multiplicity" and "no service to the estate" is not altogether happy. In this general connection, see In re National Department Stores, Ine., C. C. H., BANRRuptcy SeRvice, par. 3539 (D. Del. 1935); In re Paramount-Publix Corp., id., par. 3637 (S. D. N. Y. 1935), and same case on appeal, id. pars. 4178,4179 (C. C. A. 2d, 1936).

a But see Developments in the Law-77B (1936) 49 Harv. L. REv. IIII, Ir59. The statement in that note that ". . . the courts have taken at face value the provisions of Section $77 \mathrm{~B}$ dealing with com- 
2. Deposit agreements are indistinguishable, with comparatively few exceptions, in respect of powers vested in committees and rights surrendered by depositors, from those in use by committees not subject to $77 \mathrm{~B}$.

3. In the comparatively few instances where courts have required changes in deposit agreements as a condition to approval, the changes generally consist in modification of the provision for assessment upon withdrawal, usually in the form of setting a maximum for the assessment. This maximum is usually a liberal figure, around $2 \%$ of the face value of the securities.

4. Courts have in some instances "disregarded" deposit agreement provisions. Some instances of this are not reflected by the record of the proceedings. One instance is known, however, in which the court conditioned its order approving the deposit agreement by providing that dissent from the plan could be entered by any security holder without withdrawal of his securities; if withdrawal were sought, no charge could be imposed unless first authorized by the court. Provision for dissent without withdrawal has been made in several other proceedings.

5. The records studied indicate that only in a very small percentage of cases did the court make any investigation of the qualifications of committee members. ${ }^{62}$

6. The courts have apparently exercised considerable discretion in awarding compensation and allowing expenses out of the estate. ${ }^{63}$

In short, the record of court supervision, on the whole, is not reassuring. Individual cases there are in which the court has exercised in the fullest way its power over the reorganization process. But by and large, the record is one of formalismof compliance with the forms of the new procedure without materially affecting the old patterns of behavior. By and large, neither the broad provisions of $77 \mathrm{~B}$ nor the specifications of Section 3(a)(I0) of the Securities Act seem to have resulted in substantially fuller disclosure of material facts concerning the qualifications of committee members or their plans. By and large, the courts have not insisted that disclosures be made comparable to those required for registration under the Securities Act. Nor have they generally brought about changes in the methods of effecting reorganization and in the character of reorganization plans which would make disclosure to security holders of secondary or theoretical importance only.

The relevancy of these conclusions to any appraisal of the effect of the Securities

mittees, and in numerous instances have utterly disregarded any deposit agreements and committec authorizations that appeared unreasonable" is not supported by the study referred to in the text. It is probably true, however, that powers of serutiny were exercised in many cases in an informal fashion, not reflected in the records which were analyzed.

* But see In re Rosenbaum Grain Co., supra note 6o. In one of the cases studied in the Northern District of Illinois, a plan was rejected for several reasons, including the facts that "a history of the committee members and their qualifications had not been submitted to the Court," the deposit agreement had not been submitted, and the committee had failed to advise the court of the charges which it contemplated making to depositing bondholders.

In addition, the indirect influence upon committee personnel of the court's attitude toward allowances of fees and expenses should not be overlooked.

- Sec $577 \mathrm{~B}(\mathrm{c})(9)$ and note 60 , supra. 
Act upon reorganization procedure is readily seen. If they are accurate, the result is that a large number of reorganizations have been exempted from the disclosure requirements of the Securities Act, although no adequate or clearly better regulation obtains. The importance of these exemptions is indicated by answers which a prominent statistical agency submitted in response to an inquiry as to the assistance which they derived from registration statements for reorganization securities. This agency stated that registration statements generally were not available until after a reorganization plan had been confirmed. Consequently, the agency had to advise its clients as to depositing with protective committees and assenting to plans of reorganization without the benefit of the information generally elicited in a registration statement. It indicated that registration statements, when available, were of assistance to its work. The agency's reply to the inquiry was the following:

"x. To what extent registration statements are used in our work regarding reorganization plans.

"The answer is that we do not use these statements in deciding whether a plan is or is not equitable. Most of the cases we handle are under the amended Bankruptcy Act and registration statements are not available until after the plan is confirmed by the court and new securities are to be issued. Obviously, we must advise our clients long before the court confirms the plan.

“2. Whether registration statements have materially facilitated our work.

"As explained above they have not helped in forming an opinion as to a plan, but they are used in writing up our descriptive material regarding the new securities and the reorganized company. As such they help to give a better understanding of the value of the new securities.

“3. Have the registration statements made it possible for us to obtain more information concerning Protective Committees than we could obtain without such statements.

"This is answered under query No. I."

Two propositions, I believe, follow: first, that the registration requirements of the Securities Act are applicable to an exceedingly small number of securities concerned in reorganization; and second, that adequate controls do not exist for those reorganizations to which the registration requirements of the Act are inapplicable. It is in order, then, to inquire specifically into the effectiveness of the registration requirements of the Act and of the theory of the disclosure in the comparatively few reorganization situations where registration is required.

\section{Lists of Security Holders}

Before discussing the basic aspects of registration, it is convenient to comment upon an important phase of registration under the Commission's prescribed forms which relates to a matter of vital concern in reorganizations. This is control over lists of security holders. It has long been recognized that one of the keys to the control by management and bankers over reorganizations is their possession of and 
ability to obtain the names of security holders. ${ }^{54}$ Because of this, they have been able to communicate, with investors and to win their support. By the same token, opposition to the management and bankers has been subject to great difficulties. Without lists, the opposition has been under a terrific handicap in presenting its case to security holders and marshalling their support.

The forms prescribed by the Commission for registration of certificates of deposit have provided that a list of persons to be circularized must be filed with the registration statement or that such a list must be made available for examination. ${ }^{05}$ Lists of holders would thereby presumably be available to opposition groups. ${ }^{80}$ This move, promising as it seems, has been of little ascertainable utility. The lists filed with the Commission have generally contained a mere handful of names, and it is said that many of these were not names of security holders. Perhaps the explanation for this is that accurate and substantial lists were not available to the committees filing statements at the time of filing. It is not unreasonable to suspect, however, that some of these committees obtained accurate and fairly complete lists shortly after beginning to solicit. While it may be unusual for a committee to begin its activities with a complete list of every beneficial holder, even though the committee is sponsored by management and bankers, it is not customary for such a committee to begin operations without a substantial number of accurate names. Management and bankers are in the habit of making preparation in this respect for a rainy day. ${ }^{87}$

\section{The Theory of Disclosure as Applied to Reorganizations}

Turning to the basic theory of disclosure in the Securities Act, I believe that it is inadequate, both in theory and in practice, to provide the controls for reorganizations which are necessary. In the first place, in theory, disclosure is of little practical utility to investors whose securities are involved in reorganization. It may be true that all that need be done to aid the public in making judgments as to the advisability of buying securities, has been done when they are given complete and accurate information. Prospective investors have, by and large, a real choice-to buy, or not, as their judgment indicates. But a holder of defaulted securities has no such free choice. He holds the securities and his choice is drastically limited. In the typical situation, a protective committee preempts the field, and the holder must go along with it or accept the possibility of less favorable treatment. ${ }^{88}$ The existence of a

${ }^{4}$ See S. E. C., op. cit. supra note 3, Pt. III, pp. 252 et seq., Pt. IV, Pp. 67 ef seq. Section 77B(c)(4) provides that the court may direct the debtor to prepare lists of all known bondholders, claimants and stockholders, which will be available to the inspection of any stockholder creditor of the debtor.

- See Forms D-I and D-xA.

* In this connection, see note 64 , supra, and especially S. E. C., op. cit. supra note 3, Pt. III, PP. 252 et seq., discussing the procedure adopted by Mr. Justice Lockwood of the New York Supreme Court for controlling lists.

${ }^{7}$ See, for example, the instances in which trustees friendly to or identified with management or bankers have delayed notice of default while protective committee machinery was being perfected and strategy formulated, related in S. E. C., op. cit. supre note $3, \mathrm{Pt}$. VI, Pp. 37-42.

- It is impossible within the limits of this article to discuss the treatment accorded dissenters in reor. ganization. It must suffice to say that the history of reorganizations shows that they have generally

h. 
strong and able opposition committee is unusual. The "inside" committee, usually sponsored by management and bankers, offers the security holder a take-it-or-leave-it proposition. In this situation, he can derive small comfort from the possible disclosure of facts leading him to believe that the protective committee is composed of rascals and the plan is oppressive.

Furthermore, the disclosures in the registration statement present the facts as of the effective date of the registration statement. ${ }^{69}$ At that time, the committee may not have formulated or approved a plan of reorganization. The statement may indicate a protective committee composed of qualified individuals. On the basis of these facts, the security holder may deposit his securities. Subsequently the committee may promulgate a plan of reorganization which is unsound or unfair to depositors. Even if the complete facts with respect to this reorganization plan are disclosed, there is nothing which the security holder can do. Under the typical deposit agreement he has irrevocably surrendered dominion over his securities and he can compel their return to him only in a few instances and under oppressive conditions. ${ }^{70}$ After the security holder has deposited, he has absolutely no control over the protective committee. In some respects, he does not have as much power over the committee as a stockholder has over the management of his corporation. A stockholder, for example, may vote for new directors if he is displeased with the old. But in the present state of reorganization law and practice, the depositor has no comparable control over the personnel of his committee. ${ }^{71}$

In short, none of the practices in which protective committees are currently engaged is forbidden by the filing of a registration statement. If the registration statement contains no misstatements or non-disclosures of material facts, protective committees may continue, without restraint so far as the Securities Act is concerned, to operate under oppressive deposit agreements; they may continue to vote themselves such fees and expenses as they decide; they may continue to trade in the securities which they purport to represent; and they may continue to distribute patronage with scant regard for the interests of their beneficiaries. Under the Securities Act, the

received less favorable treatment than assenters; at best, they have been compelled to accept the same treatment. There are exceptions, as in certain well-known reorganizations in which dissenters were paid of in full. This matter will be discussed in forthcoming reports of the S. E. C. to Congress. For a discussion of some aspects, see S. E. C., op. cit. supra note 3, Pt. VI, pp. $6 \mathrm{r}-66$.

- But see Securities Act, $\$ 10(b)$, requiring that information in prospectus be as of date not more than twelve months prior to its use. The Federal Trade Commission has ruled that "It is . . . unnecessary, and probably impossible, to amend it [the registration statement] to include facts which occur after its effective date." Securities Act Release No. 97, Pt. 14, Dec. 28, 1933. The same conclusion is expressed in Matter of Howard, I S. E. C. 6 (March 21, 1934). The legal basis for this conclusion, the Commission found in $\$ 11$ of the Act which determines civil liability by reference to the date when registration becomes effective. This is not the place to analyze the accuracy of this conclusion as a matter of statutory construction or to discuss its wisdom.

${ }^{70}$ With few exceptions committees require payment of an assessment as a condition to withdrawal; and withdrawal can be effected only if request therefor be made within a specified time (usually 15 to 30 days) after notice of acerual of the right is given by the committee.

${ }^{72}$ Committees are, with few exceptions, self-perpetuating. Their deposit agreements give them the right to remove and select committee members. 
Commission has no power to regulate practices in any of these respects. And in part because of the monopolistic position of most committees; in part because of the failure of security holders to ascertain the facts set forth in the registration statement or to appreciate the significance of known facts; because of high-pressure solicitation methods of committees; because of the failure of committees to make full, current disclosures after filing their registration statement; and in part because of the perennial faith, trust and innocence of investors, these committees can obrain control of securities and effect reorganizations.

It is clear that in some cases the Commission's vigilance has stopped the activities of committees which did not deserve the confidence of investors. This result was obtained through vigorous enforcement of the disclosure requirements of the Act. But the machinery of the Act was not designed to accomplish the result; the Securities Act was not drafted or designed to provide effective control over reorganizations. It permits the escape of many committees which should not be allowed to operate. License to function depends not upon the qualification of the committee as a fiduciary, but upon the comparatively irrelevant fact of the extent of disclosure made.

An example of the inadequacy of the principle of disclosure under the Securities Act is afforded by an incident arising in connection with a registration statement filed by a committee representing debentures of a foreign industrial issuer. The committee had approved a plan of reorganization and in order to solicit deposits under the plan, it filed its registration statement. When originally filed, the statement specified that persons who had deposited their securities prior to approval of the plan might withdraw upon payment of \$10 for each \$1000 face amount of debentures. It was further stated that this payment represented the depositor's "pro rata share" of the accrued expenses and liabilities of the committee. Most of the expenses of the committee had been paid, however, by the bankers who underwrote the securities. The sum remaining to be paid, divided pro rata among the committee's depositors, did not amount to $\$ 10$ per $\$ 1000$ debenture. This was called to the registrant's attention by the Registration Division of the Commission. An amendment was filed which technically cured the inaccuracy. The amendment merely recited that the contributions to the committee's expenses made by the bankers would "not inure to the benefit of withdrawing depositors." It also eliminated reference to the withdrawal fee as the depositor's "pro rata share" of committee expenses. The result is that a security holder wishing to dissent from the plan must, after the amendment as before, pay $\$ 10$ per $\$ 1000$ debenture. The registration statement, however, is technically accurate and complete in respect of this item.

Further evidence of the inadequacy of the principle of disclosure for regulating committees can be cited. Committees have effected registration under the Act and have functioned effectively although they represented and served interests opposed to those of the security holders whose support they sought. Success has attended 
efforts to consummate plans which seem, superficially, to be oppressive even though the registration statement discloses its apparently oppressive features. A case of the latter sort involved a filing by an issuer on Form A-2 of stock issues to be exchanged for outstanding shares of the company. The plan concerned the corporation's outstanding Class A and Class B shares. No equity existed for the Class B stock, substantially all of which was held by the officers and directors of the registrant. Nevertheless, the plan provided that one share of new Class B stock would be issued for each outstanding " $B$ ". share, while for five shares of the old " $A$ " stock there would be issued six shares of new class $A$ and five shares of new "B."

The registration statement as originally filed did not clearly disclose the comparative position of the holders of each class of stock, before and after the plan, in respect of their asset position. The registrant was required to file an amendment to the statement. As finally amended and distributed to stockholders, the prospectus of the plan contained on its cover page a table clearly showing that the Class B shares had no book value before the plan; that after giving effect to the plan, they had a book value of over $\$ 6$ per share; and that the book value of each five shares of " $\mathrm{A}$ " stock was reduced by the plan from over $\$ 260$ to about $\$ 184$.

After the registration statement became effective with such disclosures, the company obtained approval of 84 per cent of Class A stockholders and of 96 per cent of Class $B$, apparently sufficient to consummate the plan. A minority brought suit to restrain consummation of the plan. This suit may have been, in part at least, the result of the clear disclosure compelled by the Commission. But on its face, at least, this case is a pointed indication that disclosure itself may not be enough.

Still further evidence of the deficiency of the principle of disclosure in respect of reorganization can be found in the history of the committee for the bonds of Chestnut Hill Apartments. This committee effected registration under the Act. ${ }^{72}$ The registration statement disclosed, in cold and devitalized answers to several items, that the issue had been underwritten by S. W. Straus \& Co. of California; that the four committee members were officials of Straus companies; that "the Committee is advised that S. W. Straus \& Co., Incorporated, a New York corporation, holds directly or indirectly the title to the property. ..."73 No apprehensive shudders are likely to afflict the reader upon reading these facts as related in the registration statement. And judging from the success of the committee in obtaining deposits, either the facts in the registration statement did not cause alarm or they did not become known to security holders.

But the record of the investigation and hearing by the Commission, as part of its Protective Committee Study, in the matter of the same issue, conveys quite a different impression. ${ }^{74}$ The facts disclosed in the registration statement are not shown to be inaccurate or necessarily incomplete. They are embellished with a full background of circumstances and with a development of motive which, I believe,

\footnotetext{
72 Hearing before the S. E. C., In the Matter of S. W. Straus \& Co. (1935) Commission's Exhibit I98.

"Reply to item 2I, supra note 72.

"Supra note 72.
} 
show that this committee was disqualified to represent holders of these bonds. I cannot attempt in this article to relate the complete story as it is reflected in the record. It must suffice to say that Straus had made advances to meet payments of principal and interest on the bonds in 1927,1928 , and $1929 .{ }^{75}$ To secure these advances, the issuer gave Straus a second mortgage and Straus cancelled the bonds and coupons which it had acquired as a result of the advances. ${ }^{76}$ Subsequently, Straus foreclosed the second mortgage and acquired title. ${ }^{77}$ During all this time it was preventing default on the first mortgage by advancing funds from its own cashbox. ${ }^{78}$ During all this time it was selling bonds of the issue at par. ${ }^{79}$ In February, 193I, Straus sought to obtain from its bondholders a "voluntary" agreement extending the maturity of their bonds. ${ }^{80}$ This plan was abandoned because of failure to get enough consents to prevent the remaining, non-assenting bondholders from compelling the trustee to foreclose. ${ }^{81}$ In 1932 , the committee which subsequently registered under the Securities Act proposed a plan of reorganization under which 45 per cent of the voting trust certificates would be issued to Straus of California in payment for title to the property. ${ }^{82}$ There was no evidence that any equity would remain after foreclosure of the first mortgage for surrender of which this stock would be issued to Straus. The contemplated payment to Straus was abandoned by the committee only after receivership, when such payment would have inured to the sole benefit of Straus creditors. ${ }^{83}$ None of the above transactions was disclosed in the registration statement. Some of them, of course, might be disclosed if the Commission's form required disclosure of past endeavors to reorganize the securities for which certificates of deposit are offered. But in the main, comparison of the record of the hearing with the registration statement indicates not deficiency in the Commission's form, but basic inadequacy of the technique. The committee which effected registration of this issue should have been absolutely disqualified to represent holders of Straus bonds. ${ }^{84}$ Only the circumstance that Straus became insolvent prevented the committee from depriving bondholders of control of the enterprise and of 45 per cent of the equity. The most complete disclosure possible probably would not have prevented this. The application of elementary standards for fiduciaries $^{85}$ would result in disqualifying this committee, because of its pecuniary stake in and connection with Straus, the underwriter and equity owner.

From another point of view, the inadequacy of the theory of disclosure as applied to committees can be demonstrated. There is no evidence that the requirement of disclosure has caused modification of practices of the protective committees which have registered under the Act. The deposit agreements of these committees, as in

Id., at I008, 10II, 1012.

"Id., at roi6-ior7.

${ }^{73}$ Id., at $102 \mathrm{I}$.

${ }^{\infty}$ Id., at 1053 .

Id., at III4-1II5.

* See S. E. C. op. cit. supra note 3, Pt. III, Pp. roo et seq.

"Id., at roig.

Id., at 1022-1023.

ald., at 1058-1060.

Id., at I125-1 126.

- For cases stating that members of protective committees are fiduciarics, see Note (1936) ${ }_{4} 6$ YALE L. J. 143 , notes 15 and 16 . 
the case of the committees which have not registered, generally vest in the committee title to or complete dominion over the deposited securities.

The committee is given power to pledge the securities in all but a few instances. A few of the deposit agreements give depositors no privilege of withdrawing their securities. Generally depositors may withdraw when the committee adopts or approves a plan, or amends a plan or its deposit agreement. In a minority of instances withdrawal is permitted in the discretion of the committee or upon abandonment of the plan. But in virtually all instances where withdrawal is permitted, it is conditioned upon prompt action and payment of assessments-requirements which make the privilege illusory as to most investors. Security holders are by and large unwilling to pay out money. The result of these restrictions upon withdrawal is that committees, once securities have been deposited, may deal with them virtually as they please, with complete immunity. They can adopt a plan, modify their deposit agreement, pledge the deposited securities and vote themselves fees and expenses with very little danger of effective dissent.

The deposit agreements for these committees indicate little improvement respecting restrictions upon profits which the committees may make from their activities. In most of the deposit agreements, express provision is made for committee members to vote themselves compensation and payment of expenses. In a majority of the instances, there is no maximum limitation upon fees or expenses; only a few make any provision for independent review of the compensation which they are empowered to vote themselves. In about one-fourth of the agreements, there is no provision for an accounting; in a. few, accounting is discretionary with the committee. Most of the agreements providing for accounting stipulate that the accounting is conclusive upon all depositors who do not object or bring legal proceedings (or in some cases, both) within 15 or 60 days.

Moreover, the usual channels of profit in addition to direct receipt of fees and expenses are left open to members of committees which have filed registration statements. By express permission, many of them may trade in the securities called for deposit, acquire a pecuniary interest in the property, and make loans to the committee secured by pledge of the deposited securities. In only a handful of instances is trading in the securities called for deposit expressly forbidden; in about half, it is expressly permitted. In only a very few agreements is the acquisition of pecuniary interest in the property forbidden; in most, it is expressly sanctioned. About half the agreements authorize members to make loans to the committee, secured by pledge of the deposited securities. The possibility of additional patronage for committee members is assured by a variety of provisions in addition to the above. Significant among them are provisions allowing committee members to underwrite the securities to be issued under the plan, or to become officers, directors or voting trustees of the new company. To protect themselves from liability in the exercise of these broad powers and in the exploitation of opportunities for profit, virtually all 
of the committees have inserted in the deposit agreements blanket exculpatory provisions, exempting them from liability except for fraud or wilful negligence.

It does not appear that the necessity to disclose has resulted in committee members whose interest in the situation arises solely from ownership of the securities. On a majority of the committees which filed registration statements, one or more members are connected with the underwriter of the securities represented; over half are affiliated with the trustee; some are connected with the issuer of the securities; and about half are affiliated with the depositary for the committee. ${ }^{88}$ On the other hand, in about 52 per cent of the committees, not a single member personally owned any of the securities which the committee represented; and in 28 per cent of the cases, no member either owned any of the securities or was affliated with a firm or corporation which owned any. In only a few cases do a majority of the committee members or their affliates own any of the securities called for deposit.

\section{Conclusions}

In the aggregate, then, it is clear that registration limited to disclosure under the Securities Act has not effected changes in protective committee qualifications or practices, nor has it exercised noticeably beneficent influence upon any important aspect of reorganization procedure. In fact, the elaborate evidence which has been summarized above is hardly necessary for the conclusion. The provisions of the Act themselves show that the registration requirements are applicable to comparatively few issues of reorganization securities, whether they be certificates of deposit or securities issued for exchange under the plan. Even if registration were required of all reorganization securities, sound theory indicates that the beneficial-results would be slight. As I have discussed, disclosure is itself inadequate to protect investors in reorganization because of the absence of genuine opportunity for the expression of will and judgment. And nothing more than disclosure can be expected from registration under the Securities Act, in respect of reorganization securities.

In connection with the offering of new issues for purchase, it may be that disclosure of material facts and intelligent administration of disclosure requirements will exert influence over practices, pervasive and substantial, although subtle and gradual. This may result from inability readily to sell unsound securities if their weakness is disclosed, and from administrative suggestion. ${ }^{87}$ But disclosure cannot

\footnotetext{
Instances are known of persons becoming members of committees in order that banks with which the, are connected may be appointed as depositary for the committee. Sce S. E. C. op. cil. supra note 3, Pt. IV, pp. 72-73.

ar Suggestions made by the Commission or its officers may be accepted for a variety of reasons including the prestige of the Commission, desire to win its favor, or the recognition of the wisdom of the suggestions themselves. In addition, they may be adopted because the registrant wishes to induce the Commission to exercise its discretionary powers in favor of the registrant. That the Commission has adopted a broad view of the function of its discretionary powers is evidenced by statements in several of its opinions. It has stated that it will not exercise its discretion to consider the situation as of the time of a stop order preceding, if such consideration will "permit the registrant to escape the consequences of a neglect id folly that approaches fraud." Matter of Haddam Distillers Corp., I S. E. C. 37, 47 (1934). Sim. 'arly, it has proceeded with publication of findings and opinion despite consent to entry' of a stop-order.
} 
be expected similarly to affect the pattern of the institution of reorganization or the practices which thrive therein. There are several reasons for this. In the first place, the usual registrant of reorganization securities need not fear that disclosure will seriously hamper its success. I have already related the principal reasons for this. With respect to committees, there is the fact of virtual compulsion upon the security holder to deposit and the monopolistic position of most committees. With respect to securities issued under a plan of reorganization, there is the fact that most of the securities to be exchanged generally are committed to the plan. In the second place, reorganizers generally conduct themselves in accordance with a well-defined cultural pattern, sanctioned by time and acceptance by the leaders in finance and law. There are no formulated standards to guide them except the practices of their predecessors and contemporaries. From this viewpoint, they do no wrong, regardless of the injury they inflict upon investors, since they abide by the only existing code. The Securities Act provides no code; it merely prescribes that they show what they are doing-that they confess and so, perhaps, win absolution. In this state of affairs, there being conformity to usage, good or bad, neither conscience nor the law need prick. In the third place, little can be expected from administrative suggestion in respect of raising reorganization standards. Wise administrators may, by discussion and analysis, use the requirement of disclosure to educate the registrant's attorneys. Questions and discussion, directed to the accuracy of statements, may raise the possibility that the propriety of a practice is subject to challenge. Subtle appeals to a higher self may cause slight changes in practices. But the limitations of such possibilities are indeed strict. Perhaps the imponderable effect of an agency with high standards may in time permeate tise practices of men; but skepticism concerning this possibility is indicated. Unless the administrator has effective bargaining power, little can be expected. It must have sanctions or desired favors which it can trade for changes in practices. Once in a while under the Securities Act, the administrator will have something to trade. It may have a choice as to whether a particular statement will be considered accurate and complete, or deficient. It may be asked to exercise its discretion, for example, to accelerate the effective date of registration. Then, if the need of the registrant is sufficiently urgent, a trade may be consummated. In return for the favor of the administrator, the registrant may amend its - practices in accordance with the administrator's conception of equity and justice. ${ }^{\mathbf{8 8}}$

There is no doubt in my mind that the Commission and its employees have utilized their powers in respect of reorganizations in a way which is remarkably worthy of commendation. The opportunities for exercise of administrative influence in connection with reorganization securities have probably been less frequent than

\footnotetext{
In the Matter of Big Wedge Gold Mining Corp., I S. E. C. 98, 100 (1935); In the Matter of General Income Shares, Inc., I S. E. C. IIo, III (I935).

In my opinion, this is an earmark of wise and effective administration. But compare the opinion of the Supreme Court in Jones v. Securities \& Exchange Commission, 298 U. S. I (1936).

${ }^{\&}$ Note particularly the Commission's power to accelerate the effective date of amended registration statements. Securities Act, $\$ 8$.
} 
in the case of other issues. The principal reason for this is that in the former there is not the same pressure of time inducing the registrant to yield a substantive point rather than incur the delay incident to amendment. Typically, the prospective issuer of certificates of deposit or, to a less extent, of securities issued under a reorganization plan is not faced with the same degree of necessity of qualifying before expiration of a time limit upon an underwriter's commitment, or while an uncertain market is advantageous. Typically (although there are exceptions) it can take the necessary time to remedy such deficiencies as the Commission may cite, without bargaining for favorable exercise of administrative discretion. And, as I have said, generally it has little to fear from disclosure. Even so, inquiry and suggestion by the Commission have sometimes led to changes such as adoption of a maximum limitation upon fees and expenses, liberal though it may have been. In addition, inquiry in respect of both registered securities and non-registered issues ${ }^{89}$ has probably resulted in some instances in voluntary modifications or changes in committee practices of a minor nature. And in some cases, alert inquiry and vigorous insistence upon full disclosure of all facts have put an end to the activities of committees which did not deserve the privilege of acting for security holders. The very fear of the Commission's inquiry has possibly dissuaded wishful entrepreneurs from forming committees; in others it is likely that manifestation of the Commission's vigilance has caused registration statements to be withdrawn. In some cases hearings have been held on registration statements for reorganization securities, and the attendant publicity has undoubtedly been salutary. In the reported cases involving reorganization securities in which the Commission has issued stop orders, it seemed eminently desirable that the committees concerned be forbidden to solicit deposits. One of these concerned a registration statement for certificates of deposit to be issued by Commonwealth Bond Corporation "as a committee" for bonds of an issue originally underwritten by Commonwealth. ${ }^{90}$ Another concerned a committee none of the members of which was beneficially interested in the securities called for deposit. ${ }^{91}$ Both stop orders were, of course, based upon failure to make necessary disclosures; but in both instances, the qualification of the registrant to provide loyal representation to bondholders is at least questionable.

On the whole, therefore, it is clear, as congressional direction of the Commission's investigation of protective committees implies, that something more than the provisions of the Securities Act is necessary. If the standards of reorganization are to be raised, rules prescribing committee qualifications and regulating their practices must be prescribed and machinery must be furnished for their enforcement, and ways and means must be found to insure the formulation of desirable plans of reorganization.

${ }^{*}$ The Commission has frequently communicated with issuers and protective committecs, in connection with non-registered issues, concerning matters raised by letters of complaint.

${ }^{\infty}$ Matter of Commonwealth Bond Corp., I S. E. C. 13 (1934).

${ }^{92}$ Matter of Charles A. Howard, et al., I S. E. C. 6 (1934). 